\title{
ARTIFICIAL PRUNING OF FOREST TREE SPECIES IN RESPONSE TO CULTIVATION METHOD
}

\section{DESRAMA ARTIFICIAL DE ESPÉCIES FLORESTAIS EM RESPOSTA AO MÉTODO DE CULTIVO}

\author{
Camila Costa da Nóbrega ${ }^{1}$, Luan Henrique Barbosa de Araújo², Gualter Guenther Costa da \\ Silva ${ }^{3}$, Ciro de Oliveira Ribeiro ${ }^{4}$, Ermelinda Maria Mota Oliveira ${ }^{5}$ \\ ${ }^{1}$ Federal University of Paraíba, Areia, Paraíba, Brazil - camila_cnobrega@hotmail.com \\ ${ }^{2}$ Federal Rural University of Pernambuco, Recife, Pernambuco, Brazil - araujo.lhb@gmail.com \\ ${ }^{3,5}$ Federal University of Rio Grande do Norte, Macaíba, Rio Grande do Norte, Brazil - \\ gualtermve@gmail.com \& ermelindasolos@gmail.com \\ ${ }^{4}$ University of São Paulo, Piracicaba, São Paulo, Brazil - cirodeoliveiraribeiro@hotmail.com
}

\begin{abstract}
This study aimed to quantify the artificial pruning of forest species sabia (Mimosa caesalpiniaefolia Benth.), acacia (Acacia mangium Willd.) and neem (Azadirachta indica A. Juss), at 12 months of age, in response to the cultivation method. The experimental design was in randomized block design in a factorial scheme $(2 \times 3)$, corresponding tosix treatments distributed in plots in tracks with four blocks. Being the main factor two methods of cultivation (less intensive - $\mathrm{CA}$ and more intensive - $\mathrm{CB}$ ) and the secondary factor the forest species, totaling six treatments with four replicates each. The growth of each tree was obtained with the measurement of the total height and diameter at breast height. For the quantification of biomass pruned selected is a tree in the surrounds of each parcel with average height and diameter. The pruning was performed until the height equivalent to $40 \%$ of the crown height of the tree. The three variables studied (leaf, branch and total) showed significant differences between the types of cultivation and between the species. Only the parameter leaf for the sabia treatment didn't show differences in relation to the cultivation types. We concluded that the cultivation method and the species types have influency in the total biomass production and consequently in the pruned plant amount.
\end{abstract}

KEYWORDS: Biomass of pruning, Increase forest, Silvicultural treatment.

\section{RESUMO}

Objetivou-se quantificar a desrama artificial das espécies florestais sabiá (Mimosa caesalpiniaefolia Benth.), acácia (Acacia mangium Willd.) e nim (Azadirachta indica A. Juss), aos 12 meses de idade, em resposta ao método de cultivo. O delineamento experimental foi em blocos casualizados em esquema fatorial (2x3), correspondente a seis tratamentos distribuídos em parcelas subdivididas em faixas com quatro blocos. Sendo o fator principal dois métodos de cultivo (menos intensivo - CA e mais intensivo - CB) e o fator secundário as espécies florestais, perfazendo seis tratamentos com quatro repetições cada. $\mathrm{O}$ crescimento de cada árvore foi obtido com a medição da altura total e do diâmetro à altura do peito. Para a quantificação da biomassa desramada selecionou-se uma árvore da bordadura de cada parcela com altura e diâmetro médios. Realizou-se a desrama até a altura equivalente a $40 \%$ da altura da copa da árvore. As três variáveis estudadas (folha, galho e total) apresentaram diferenças significativas entre os tipos de cultivo e entre as espécies. Apenas o parâmetro folha para o tratamento sabiá não apresentou diferenças entre os tipos de cultivo. Concluiu-se que o método de cultivo e os tipos de espécies influenciam a produção total de biomassa e, consequentemente, a quantidade de material vegetal desramado.

PALAVRAS-CHAVE: Biomassa desramada, Incremento florestal, Tratamento silvicultural. 


\section{INTRODUCTION}

The use of forest resources and soils in a sustainable way emerges as an alternative to the reduction of the impacts caused by the irrational exploitation of the native forest. One way to reduce the impacts caused by the irrational exploitation is through the use of silvicultural practices.

Among these practices, it stands out the pruning. The pruning has as an objective the production of wood of best quality and free from us. One of the main benefits of pruning is in the production of wood stripped of knots (without us), besides the increase of productivity (SILVA et al., 2012). These nodes are considered defects to the use of wood in the sawmill, because it interferes with the quality of the wood, both in question aesthetics as to the use that is limited (SIXEL, 2008).

In deployed stands, the thinning together with the pruning wood aim to obtain wood free of knots, with a high DAP dimension (when compared to individuals to meet the energy needs and other purposes), in order to obtain sawn wood. This lumber is currently obtained in large scale from native forests. For this reason, the lumber originating from forest plantations will minimize the removal of native wood (mainly from the Amazon forest).

The pruning can be natural or artificial. The pruning occurs naturally by the fall of dead branches and artificially by the elimination of branches to a certain height, whether they are alive or dead (MONTAGNA et al., 1976). The artificial pruning can have two objectives: cleaning or driving. The pruning of cleaning is used to remove diseased branches or mechanical damage. Already the pruning of conduct has the purpose to define one or more rectilinear shapes, leading to the production of wood (SILVA et al., 2012). According to Cezana et al. (2012), the artificial pruning is one of the factors that influence productivity.

The use of the material obtained after pruning, as a form of litter, is fundamental to the sustainability of forestry production, because it is a natural way of fertilizing, allowing part of the nutrients absorbed by plants return to the soil through the decomposition of leaf litter, and also contribute to the reduction of the impacts caused by the harvest.To perform the artificial pruning, are needed some care, among them the time of pruning. The removal of dried and dead branches can be performed at any time of the year, but for the green branches, it is important that it is carried out in the period of vegetative growth, when the healing is faster (SIXEL, 2008).

The pruning in young plants is economically more viable and contributes to the productivity of better quality of wood (PIRES, 2000).

The use of species in pure or agroforestry systems, for multiple uses, represents an advance in the use of forest resources by small and medium producers, allowing the diversification of agricultural activity and the use of areas with low productivity (BARBOSA et al., 2008).

In some cases, inadequate management of forests is caused by ignorance of the factors that sustain the high production of biomass and maintain soil fertility (CALDEIRA et al., 2008). Soil management is a form of initial preparation that is used to create conditions for crop implantation, which may be intensive. According to Anjos et al. (2010), it is necessary in some cases to turn the soil, to improve the surface layer and to leave the soil more workable, especially in the case of being an area with historical uses.

Considering that the majority of jobs with pruning is to test the ideal percentage of pruning for certain species, litter accumulation through the natural pruning decomposition rate and quantification of nutrientes returned to the soil, this study focuses on the quantification of the pruning in accordance with the method of cultivation, in order to indicate the species with the greatest potential for production of plant biomass and, consequently, of artificial pruning, having as its purpose the use of plantations for wood production and accumulation of litter in the recovery of degraded areas.

The aim of this work was to quantify the artificial pruning of forest species sabia (Mimosa caesalpiniaefolia Benth), acacia (Acacia mangium Willd.) and neem (Azadirachta indica A. Juss), to 12 months of age, in response to the method of cultivation.

\section{MATERIAL AND METHODS}

\section{Characterization of the study area}

The study was conducted in the Forest experimentation of UAECIA (Academic Unit Specializing in Agricultural Sciences), EAJ (Agricultural School of Jundiaí, UFRN (Federal University of Rio Grande do Norte), Macaíba - RN, in the period from August to September 2013. Located under the following geographic coordinates: $5^{\circ} 54^{\prime} 05.85^{\prime \prime} \mathrm{S}$ and $35^{\circ} 21^{\prime} 25.45^{\prime \prime} \mathrm{O}$.

The experiment was established in May 2012, in a Yellow Latosol sandy texture and flat topography area (BELTRÃO et al., 1975). The local climate is a transition between the types As and BSw according to the classification of Köppen, with average temperatures throughout the year of $27^{\circ} \mathrm{C}$ and rainy autumn and winter. 
The rainfall in the region range between 800 and 1,200 $\mathrm{mm} . \mathrm{yr}^{-1}$, being characterized as sub-humid climate.

\section{Experimental design}

The experimental design was in randomized block in a factorial scheme $(2 \times 3)$, corresponding to six treatments distributed in plots in tracks with four blocks. Being the main factor two methods of cultivation less intensive - CA and more intensive - $\mathrm{CB}$ (Table 1) and the secondary factor the forest species, were used the species sabia (Mimosa caesalpiniaefolia Benth.), acacia (Acacia mangium Willd.) and neem (Azadirachta indica A. Juss), totaling six treatments with four replicates each. For each treatment, we installed four plots of $576 \mathrm{~m}^{2}$, totaling $13,82 \mathrm{~m}^{2}$ of effective planting, with spacing between plants of $3 \mathrm{~m} \times 3 \mathrm{~m}$, with 64 plants per plot and plot 36 useful plants, being 28 border plants.

Table 1. Description of the management carried out in the methods of cultivation $C A$ and $C B$ used in fores plantations of sabia, acacia and neem, in the area of Forest experimentation of UAECIA/EAJ/UFRN.

\begin{tabular}{lcc}
\hline \multicolumn{1}{c}{ Description } & \multicolumn{2}{c}{ Type of cultivation } \\
\hline Harrowing & $\mathrm{CA}$ & $\mathrm{CB}$ \\
Grooves $(40 \mathrm{~cm} \times 70 \mathrm{~cm})$ & $\mathrm{X}$ & $\mathrm{X}$ \\
Cattle manure $(4.0 \mathrm{t} / \mathrm{ha})$ & & $\mathrm{X}$ \\
Super triple $(146.0 \mathrm{~kg} / \mathrm{ha})$ & & $\mathrm{X}$ \\
Pits $(20 \mathrm{~cm} \times 15 \mathrm{~cm})$ & $\mathrm{X}$ & $\mathrm{X}$ \\
NPK $(6-30-6)(100 \mathrm{~g} /$ plant $)$ & $\mathrm{X}$ & $\mathrm{X}$ \\
Application of limestone $(2.0 \mathrm{t} / \mathrm{ha})$ & & $\mathrm{X}$ \\
\hline
\end{tabular}

A: Less intensive and B: More intensive

\section{Deployment and silvicultural treatment}

Initially they were collected seeds of sabia, acacia and neem used for production of seedlings, these were from an orchard of the site São Clemente (Macaíba, RN), EMPARN (Natal, RN) and EAJ (Macaíba, RN), respectively. The sabia seedlings, acacia and neem were produced in the nursery of the EAJ, in seedling bags with a diameter of $15.0 \mathrm{~cm}$ and $18.0 \mathrm{~cm}$ in height, using a substrate in the ratio 1:1 (bovine manure:sand). The seedlings were taken for planting in the field after two months of germination, with na average of $30.0 \mathrm{~cm}$ of height.

In the experimental area, was initially conducted the fight the ants, using Clopirifós (Klorpan - trade name) together with mineral oil (Assist) in the ratio of $50 \mathrm{~mL} / \mathrm{L}$ in thermoweller. After this step were performed two harrowings crusades across the experimental area for cleaning and preparing the soil for planting.

After the screening, were opened the furrows with 40.0 $\mathrm{cm}$ and $70.0 \mathrm{~cm}$ opening in plots with cultivation $B$, these were fertilized with cattle manure and triple superphosphate deposited at the bottom of grooves. After the fertilization, the furrows were closed and were open pits with $20.0 \mathrm{~cm}$ and $15.0 \mathrm{~cm}$ in diameter in all plots for planting. After the planting the seedlings, was applied $100.0 \mathrm{~g} /$ plant of NPK on the proportion 6-30-6 in two pits sides with $10 \mathrm{~cm}$ of depth and $15.0 \mathrm{~cm}$ of diameter, located at $15.0 \mathrm{~cm}$ from each plant. Two months after planting, the correction of the soil with the application of lime $(2.0 \mathrm{t})$ in the plots for cultivation $B$ (Table 2). The limestone was used to supply the demand of calcium and magnesium by cultures, whereas the availability in the soil was below the critical level.

\section{Data Collection}

The prunning data collection was performed at 12 months after planting. After measuring the total height $(H)$ and the diameter at breast height $(D B H)$, averages were selected trees from the edge, a tree per plot, which was performed to quantify the pruning and the total production of the tree. For 24 months, was performed new measurement of total production, to understand the influence of pruning in the increment of biomass. A border tree was used so that the useful plot was not affected in the future measurements.

For the selection of the individual of medium size of each portion of the border, took as a basis the average $D B H$ and $H$, being the average $D B H$ the diameter corresponding to the average of the sectional area of the stand (Equation 1).

$$
\overline{D B H}=\sqrt{\left(\Sigma D B H^{2} / n i\right)}
$$

(Equation 1)

Where: $\Sigma D B H=$ Sum of the diameters at breast height; $n i=$ number of individuals.

All the trees were pruned at a height equivalente to $40 \%$ of the Crown height of the tree (SIXEL, 2008). The pruning material was weighed in the field with the aid of balance, being separated into leaves and stems, for subsequent quantification total. After weighing, all the material was deposited within plots from which they were removed. Samples of approximately $200 \mathrm{~g}$ were placed to dry in a drying oven, forced to $65^{\circ} \mathrm{C}$ for 72 hours, to obtain the dry weight.

For the sabia, for being a species which has a large number of stems, were left three stems, the more 
vigorous, as proposed by Silva et al. (2012), the rest was removed and quantified as biomass of pruning. For the species acacia and neem, was left only one stem, to be characteristic of these species the growth of only one main stem.

\section{Statistical analysis}

The data were analyzed in the statistical program Assistat 7.7 Beta (SILVA \& AZEVEDO, 2016), performed the analysis of variance and applied the Tukey test for comparison of means at $1 \%$ level of significance.

\section{RESULTS AND DISCUSSION}

The quantification of artificial pruning of the components leaf, branch and total held in sabia, acacia and neem under different methods of cultivation, presented significant differences, in that for the three species, in the three variables studied, with the exception of sabia for variable leaves, the cultivation $\mathrm{CB}$ was higher in the pruned quantity in relation to the cultivation $\mathrm{A}$ (Table 2).

Table 2. Artificial pruning of the components leaf, branch and total (t/ha) for the three forest species, to 12 months of age, in response to the methods of cultivation CA (less intensive) and CB (more intense).

\begin{tabular}{cccccccc}
\hline \multirow{2}{*}{ Species } & \multicolumn{3}{c}{ Leaf } & \multicolumn{3}{c}{ Branch } & \multicolumn{2}{c}{ Total } \\
\cline { 2 - 8 } & CA & CB & CA & CB & CA & CB \\
\hline Sabia & $1.00 \mathrm{abA}$ & $1.18 \mathrm{bA}$ & $1.83 \mathrm{aB}$ & $2.65 \mathrm{aA}$ & $2.83 \mathrm{aB}$ & $3.83 \mathrm{bA}$ \\
Acacia & $1.63 \mathrm{aB}$ & $2.85 \mathrm{aA}$ & $1.19 \mathrm{aB}$ & $1.87 \mathrm{bA}$ & $2.79 \mathrm{aB}$ & $4.72 \mathrm{aA}$ \\
Neem & $0.42 \mathrm{bB}$ & $1.58 \mathrm{bA}$ & $0.43 \mathrm{bB}$ & $1.69 \mathrm{bA}$ & $0.85 \mathrm{bB}$ & $3.27 \mathrm{bA}$ \\
\hline
\end{tabular}

DMS: sheets (between species) = 0.75; sheets (between crops) 0.51; branches (between species) = 0.75; branches (between crops) = 0.50; total (between species) $=0.60$; total (between crops) $=0.40$. In that: The lower case letter compares different species for the same cultivation method and plant component. The capital letter, by what is perceived, compares the methods of cultivation for the same species and component of the plant.

In Table 2, it should be noted that the sheet variable showed a significant difference between the species, Acacia presented a greater quantity of biomass of leaves pruning compared to sabia and of neem on the two types of cultivation, but cultivation method "CA" was statistically similar to production of sabia.

According to Paula et al. (2009) the variable sheet is na important litter bin in returning nutrients to the soil. Several studies show that this bin can contribute to the greater part of the contribution of litter on the ground (MACHADO et al., 2015; BIANCHIN et al., 2016; SILVA et al., 2016; SOUZA et al., 2016).

In the variable branches (Table 3), the sabia had greater quantity pruned in relation to the other species in the two types of cultivation, being statistically similar to pruned quantity of acacia trees in cultivation " $\mathrm{CA}^{\prime}$. For total trash, there was a significant difference between the species, in which the cultivation, the sabia and acacia species showed production of top pruning the neem and cultivation, the production of the acacia was statistically superior to sabia and neem.

Although the sheets present itself as an importante material of litter, the different compartments of the same tree feature different concentrations and nutrient contente (PAULA et al., 2009), being all compartments are important for the composition of litter.
It was observed that the three species had higher pruned amount in crop CB compared to CA. On average, neem showed $74 \%$, acacia $59 \%$ and sabiA $26 \%$ more of total dry biomass in treatment with $\mathrm{CB}$ cultivation in relation to $C A$.

It is important that the pruning is performed with the plants still young, because it assists in increasing productivity. In a study conducted with Eucalyptus, Monte et al. (2009) emphasize that the artificial pruning is carried out until no later than 20 months of age.

Based on the type of cultivation for growing the pecies, sabia returned to the ground $44 \%$ of plant biomass, while the species acacia returned $65 \%$ of their biomass to the soil. The neem returned just $27 \%$ of its total dry biomass production in the form of litter to the soil (Figure 1).

It was observed in figure 1 that, for the CA crop, the sabia at 24 months, showed an increase in the production of dry biomass by approximately $52 \%$, while the acacia had approximately $112 \%$ more production in the second year compared to the first one. The total dry biomass production of neem at 24 months was $128 \%$ higher than at 12 months.

In relation to the cultivation method $\mathrm{CB}$, sabia provided $49 \%$ of total dry biomass in the soil. The acacia left $71 \%$ of its biomass to compose the soil litter. Neem in turn increased $52 \%$ litter in the soil (Figure 2). 


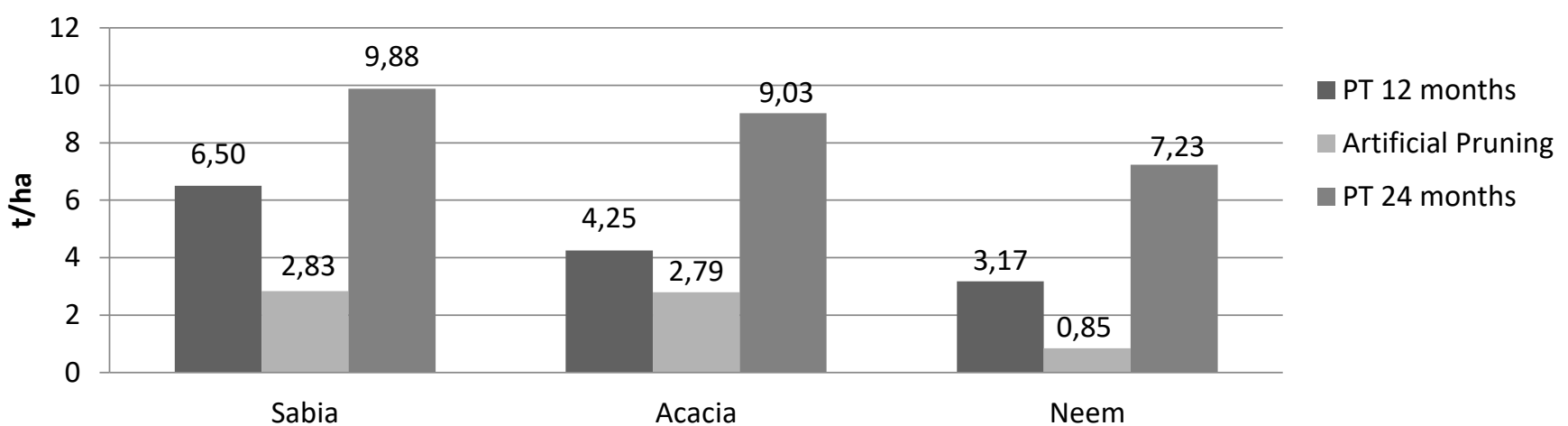

Figure 1. Total production (PT) of plant biomass at 12 and 24 months and the total artificial pruning $\left(t^{\text {th }} a^{-1}\right)$, for the three forest species in response to the method of cultivation CA (less intensive).

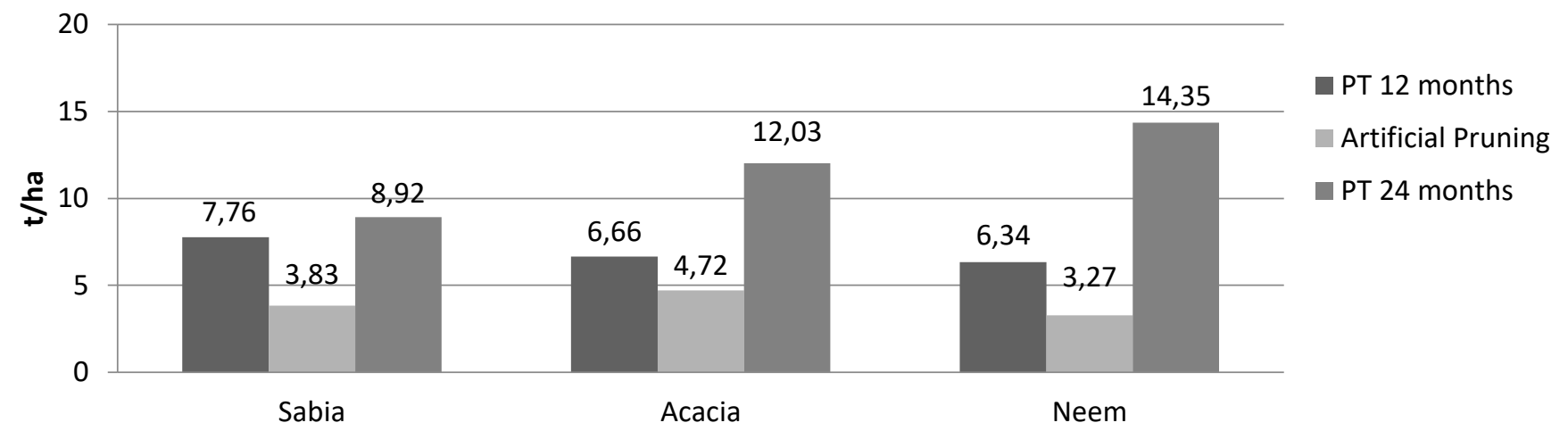

Figure 2. Total production (PT) of plant biomass at 12 and 24 months and the total artificial pruning (t/ha), for the three forest species in response to cultivation method CB (more intense).

In Figure 2, it is possible to observe that there was a difference regarding the increase of biomass for 24 months, compared with 12 months for the species acacia and neem. The sabia, for 24 months, showed an increase in the biomass production of only $15 \%$ compared to 12 months, in this way, it can be argued that the cultivation $\mathrm{CB}$ allied to pruning performed in plots did not influence the total production of biomass of sabia. The acacia presented an increase in the production of 12 to 24 months of approximately $81 \%$, already the neem produced in the second year $126 \%$ more total dry biomass for the first year, as well as the cultivation CA.

In the cultivation method $\mathrm{CB}$ the total production of plant biomass is greater in relation to the method of cultivation, in the first year, presenting in their turn the plots for cultivation CB greater amount of pruning for the three species, consequently larger amounts of litter in relation to plots with cultivation CA. In the second year, the species sabia presented total production of vegetable biomass smaller in relation to the method of cultivation, confirming the information that the cultivation CB allied to pruning performed in plots did not influence the total production of biomass, being impracticable, this type of management for the abovementioned species.
All plant material obtained in the pruning was left in the plots, composing the litter the ground causing part of the nutrients absorbed by plants could return to the ground, also helping to reduce the possible impacts and erosion which may arise in the area. According to Cunha Neto et al. (2013), the arboreal component influences the cycling of nutrients and consequently on the fertility of the soil. The litter performs multiple functions are positive for the ecological environment, providing improvement in physical attributes, chemical (HOLANDA et al., 2017) and biological properties of the soil.

\section{CONCLUSIONS}

The method of cultivation and the species influence the total production of biomass and consequently the amount of plant material pruned.

The method of cultivation more intensive (CB) obtained higher amount of total dry biomass and pruned for all three species in relation to growing less intensive (CA), to 12 months.

The method of cultivation more intensive (CB) allied to pruning had influence on the total biomass production to 24 months for the species acacia and neem. 
It is impracticable to apply cultivation method more intensive (CB) together with the pruning for the sabia, since the specie did not show increase of production in its second year, and the method of cultivation less intensive (CA) pruning more for that specie, to be economically viable. For acacia and neem species, the method more intensive $(\mathrm{CB})$ was the more indicated.

\section{ACKNOWLEDGMENTS}

The CAPES/UFRN, by granting the master's scholarship to the first author.

The GESOLO group, by aid, essential to the achievement and completion of such work.

\section{REFERENCES}

ANJOS, J.B. et al. sistema de produção de melancia: solos. sistemas de produção. Petrolina: Embrapa Semiárido, 2010. Disponível em: http://sistemasdeproducao.cnptia.embrapa.br/ FontesHTML/Melancia/SistemaProducaoMelancia/solos.htm

BARBOSA, T.R.L. et al. Plantio do Sabiazeiro em pequenas e médias propriedades. Niterói: Programa Rio Rural, 2008.

BELTRÃO, V.A. et al. Levantamento Semidetalhado da Área do Colégio Agrícola de Jundiaí - Macaíba/RN. Recife: SUDENE Recursos de Solos, Divisão de Reprodução, 1975.

BIANCHIN, J.E. et al. Deposição de Fitomassa em Formações Secundárias na Floresta Atlântica do Paraná. Floresta Ambiente, v.23, n.4, p.524-533, 2016.

CALDEIRA, M.V.W. et al. Quantificação de serapilheira e de nutrientes em uma Floresta Ombrófila Densa. Semina: Ciências Agrárias, v.29, n.1, p.53-68, 2008.

CEZANA, D.P. et al. Efeito de diferentes classes de altura e intensidades de desrama artificial sobre o crescimento de um híbrido de eucalipto. Floresta, v.42, n.1, p.137-144, 2012.

CUNHA NETO, F.V. et al. Acúmulo e decomposição da serapilheira em quatro formações florestais. Ciência Florestal, v.23, n.3, p.379-387, 2013.

HOLANDA, A C. et al. Aporte de serapilheira e nutrientes em uma área de caatinga. Ciência Florestal, v.27, n.2, p.621-633, 2017.

MACHADO, D.L. et al. Ciclagem de nutrientes em diferentes estágios sucessionais da mata atlântica na bacia do Rio Paraíba do Sul, RJ. Bioscience Journal, v.31, n.4, p.1222-1237, 2015.

MONTAGNA, R.G. et al. Influência da desrama artificial sobre o crescimento e a qualidade da madeira de Pinus elliottii. Silvicultura em São Paulo, n.10, p. 89-100, 1976.

MONTE, M.A. et al. Crescimento de um clone de eucalipto submetido a desrama e desbaste. Revista Árvore, v.33, n.5, p.777-787, 2009.
PAULA, R.R. et al. Aporte de nutrientes e decomposição da serapilheira em três fragmentos Florestais periodicamente inundados na Ilha da Marambaia, RJ. Ciência Florestal, v.19, n.2, p.139-148, 2009.

PIRES, B.M. Efeito da desrama artificial no crescimento e qualidade da madeira de Eucalyptus grandis para serraria e fabricação de móveis. 2000. 96p. (Dissertação de Mestrado).

SCHNEIDER, P.R. et al. Efeito da intensidade de desrama na produção de Pinus elliottii Engelm., implantado em solo pobre, no estado do Rio Grande do Sul. Ciência Florestal, v.9, n.1, p.35-46, 1999.

SILVA, F.A.S.; AZEVEDO, C.A.V. The Assistat Software Version 7.7 and its use in the analysis of experimental data. African Journal of Agricultural Research, v.11, n.39, p.3733-3740, 2016.

SILVA, M.P.S. et al. Desrama Florestal. Princípios de desramas e desbastes florestais. Campos dos Goytacazes: UFV, 2012.

SILVA, W.T.M. et al. Deposição de serapilheira em áreas de Caatinga no Núcleo de Desertificação do Seridó. Agropecuária Científica no Semiárido, v.12, n.4, p.383-390, 2016.

SOUZA, B.V. et al. Avaliação da sazonalidade da deposição de serapilheira em área de preservação da Caatinga na Paraíba, Brasil. Agropecuária Científica no Semiárido, v.12, n.3, p.325331, 2016.

SIXEL, R.M.M. Silvicultura e Manejo. Instituto de Pesquisas e Estudos Florestais, 2008. Disponível em: http://www.ipef.br/ silvicultura/manejo.asp 